\title{
Management of pruning and evaluation in blackberry cultivars in relation to productive characteristics and bioactive compounds
}

\author{
ADRIANA LUGARESI ${ }^{1 *}$, ALISON UBERTI ${ }^{1 *}$, CLEVISON L. GIACOBBO ${ }^{2}$, MAIKE \\ LOVATTO $^{1 *}$, GIAN C. GIRARDI ${ }^{1 *}$ and AMÉRICO WAGNER JUNIOR ${ }^{3 * *}$ \\ ${ }^{1}$ Departamento de Agronomia, Universidade Federal da Fronteira do Sul, Rodovia \\ SC 484, Km 02, Fronteira Sul, 89815-899 Chapecó, SC, Brazil \\ ${ }^{2}$ Departamento de Agronomia/PPGCTA, Universidade Federal da Fronteira do Sul, \\ Rodovia SC 484, Km 02, Fronteira Sul, 89815-899 Chapecó, SC, Brazil \\ ${ }^{3}$ Departamento de Agronomia, Universidade Tecnológica Federal do Paraná, Estrada \\ para Boa Esperança, Km 04, 85660-000 Dois Vizinhos, PR, Brazil
}

Manuscript received on May 9, 2018; accepted for publication on July 2, 2018

\begin{abstract}
The goal of this work was to evaluate blackberry cultivars in terms of productivity and bioactive compounds. Two experiments were conducted: in the first experiment four cultivars were evaluated (Cherokee, Guarani, BRS-Tupy and Xavante). In the second experiment, the effects of pruning management in the BRS-Tupy cultivar were evaluated with the following treatments: drastic winter pruning (zero primocane), and maintenance of two, three or four primocanes in the winter pruning. Vegetative, productive and fruit quality characteristics were determined, including measurement of bioactive compounds. Among the cultivars, the cultivar BRS-Tupy was superior in terms of productive characteristics, but for content of anthocyanins and flavonoids, the cultivar Xavante stood out (191.97 and $68.44 \mathrm{mg} 100 \mathrm{~g}^{-1}$, respectively). Drastic winter pruning produced lower fruit quality. The number of primocanes has a directly proportional influence on the soluble solids content and productivity component. For farmers who want fruits with greater levels of bioactive compounds, the use of cultivar Xavante is recommended; however, for those who aim for productive aspects, we suggest the use of cultivar BRS-Tupy with four primocanes per plant.
\end{abstract}

Key words: Rubus sp., primocane management, bioactive compounds, cultivars.

\section{INTRODUCTION}

Over the last several decades, the increase in demand for fresh fruits for improved health has generated a market demand for fruits with better intrinsic and extrinsic qualities. The consumption

Correspondence to: Adriana Lugaresi

E-mail: adrianalugaresi@yahoo.com.br

* Bolsista FAPESC/UFFS

***Bolsista PQ/CNPq of blackberry (Rubus sp.) has grown along with demand in the fruit market, primarily because it possesses nutraceutical properties that help fight several diseases (Tadeu et al. 2015).

The blackberry is highly sought-after because it is nutritionally rich, containing sugars and dietary fiber, as well as basic nutrients and secondary metabolites, including phenolic compounds and carotenoids (Ferreira et al. 2010, Hirsch et al. 
2012). Among the compounds found to confer natural pigmentation are anthocyanins that attract consumers with their visual properties (Campagnolo and Pio 2012b). For these reasons, blackberry is an attractive alternative for fruit growers in Western Santa Catarina, Brazil.

It is necessary to perform summer pruning to reduce the length of new primocanes, in order to provide for the formation of larger numbers of floricane (Takeda 2002, Campagnolo and Pio 2012a). According to Takeda (2002), in addition to summer pruning, one must also perform winter pruning, in which one selects the most vigorous primocanes, in addition to adjusting the pruning in the floricane.

It is important to emphasize that plants having all their aerial parts removed will experience greater difficulties producing satisfactorily, because of low content of reserves and limited reproductive structures available for fruiting. (Campagnolo and Pio 2012a, Villa et al. 2014). Furthermore, the edaphoclimatic conditions where the plants are cultivated have substantial influence on the productive performance of the cultivars (Ferreira et al. 2016).

Our hypothesis was that winter pruning influences the bioactive compounds of blackberry fruits and varies according to the cultivar studied.

Therefore, the aim of this study was to evaluate the productive capacity and bioactive compounds in fruits of blackberry cultivars according to pruning management.

\section{MATERIALS AND METHODS}

The study was carried out in the Experimental Area of the fruticulture sector and in the Fruit and PostHarvest Laboratories of the Federal University of Fronteira Sul - Chapecó, Santa Catarina (SC), Brazil, and in the Laboratory of Plant Physiology of Federal University of Technology of Paraná Dois Vizinhos - Paraná (PR), Brazil. The orchard is located at $27^{\circ} 07^{\prime} 11^{\prime \prime S}$ latitude, $52^{\circ} 42^{\prime} 30^{\prime \prime} \mathrm{E}$ longitude, at an altitude of $610 \mathrm{~m}$. The local climate according to the Köppen classification is category C, subtype HSC (humid subtropical climate).

The planting of blackberry saplings was carried out in 2014, with spacing of $1.5 \mathrm{~m}$ x 3.0 $\mathrm{m}$ (density of 2.222 plants $\mathrm{ha}^{-1}$ ). The experiments were carried out during the first production cycle, agricultural year 2015/16.

We conducted two experiments, the first based on a test of cultivars and the second involving pruning management. Experiment 1 was conducted with a completely randomized design with four treatments corresponding to 'Cherokee', 'Guarani', 'BRS-Tupy' and 'Xavante' cultivars, with five replicates and one plant per experimental unit, each plant maintained with three primocanes.

In experiment 2, the same design, number of replications and experimental units were used. There were four management prunings for the BRS-Tupy cultivar (cv.): drastic winter pruning (zero primocane), and maintenance of two, three or four primocanes after pruning.

For the two experiments, we evaluated vegetative variables, including mean leaf area, green matter mass and leaf dry mass percentage. The mean leaf area was obtained with the aid of a foliometer, and data were expressed in square centimeters $\left(\mathrm{cm}^{2}\right)$.

To obtain mean green leaf mass, five leaves were evaluated at the height of the middle third of the plant, and a digital semi-analytical balance was used. Mass was expressed in grams (g). For analysis of dry matter mass, a forced-air circulation oven was used at a temperature of $65^{\circ} \mathrm{C}$, up to constant weight, calculating dry matter as a percentage mean green leaf mass.

For production variables, we evaluated productivity $\left(\mathrm{Kg} \mathrm{ha}^{-1}\right)$, number of fruits per plant and average fresh matter mass of fruit $(\mathrm{g})$. The physicochemical and bioactive compounds variables were mean volume of fruit, soluble 
solids, total anthocyanins, flavonoids and phenolic compounds.

To verify average fruit size, a $100 \mathrm{~mL}$ graduated column $( \pm 1 \mathrm{~mL})$ was used, in which a fixed amount of water had been placed, after which five fruits were added; in all, six repetitions were performed. The difference in water volume was divided by the number of fruits added to the graduated column.

Soluble solids contents were measured with a digital refractometer, expressed in Brix degrees. For the determination of bioactive compounds, a $100 \mathrm{~g}$ sample of fruits was homogenized in the puree form and $1 \mathrm{~g}$ was weighed for each analysis. The content of anthocyanins and flavonoids were measured according to the methodology of Lees and Francis (1972) by spectrophotometry. Values were expressed in milligrams per 100 grams fresh fruit mass (mg $100 \mathrm{~g}^{-1} \mathrm{FM}$ ). For the analysis of phenolic compounds, we adopted the Georgé et al. (2005) modification of the Folin-Ciocalteau methodology. Values were expressed as milligrams of gallic acid equivalent per hundred grams of fresh fruit mass (mg GAE $100 \mathrm{~g}^{-1} \mathrm{FM}$ ).

The data were subjected to analysis of variance by the $\mathrm{F}$ test and, when significant, the means were compared by the Tukey test $(\mathrm{P} \leq 0.05)$.

\section{RESULTS AND DISCUSSION}

\section{EXPERIMENT 1}

With respect to vegetative characteristics, cv. Xavante showed greater vigor than did the other cultivars in the edaphoclimatic conditions of Western Santa Catarina (Table I. The cultivars Cherokee, Guarani and BRS-Tupy did not differ significantly from one another with respect to mean leaf area and green matter mass of the leaves.

With respect to mass of leaf dry matter in the various cultivars, no significant differences were observed (Table I), suggesting that the variation presented in the green matter mass of the leaf of cv. Cherokee was associated with its mean leaf area, allowing greater accumulation of water, demonstrating superiority.

We observed that cv. BRS-Tupy was superior to the other cultivars in terms of productive yield variables, presenting the highest averages for size, fresh matter mass and number of fruits, in addition to productivity (Table I). The Cherokee, Guarani and Xavante cultivars did not significantly differ from one another.

Curi et al. (2015) studied cultivars in Lavras, Minas Gerais (MG), Brazil, and reported that the average fruit size of the Guarani and BRS-Tupy cultivars were similar, suggesting that there were no variations in the different regions. Ferreira et al. (2016) reported superior results for BRS-Tupy and Xavante cultivars, and lesser results for cv. Guarani, grown in Pelotas, Rio Grande do Sul (RS), Brazil.

In terms of the number of fruits per plant, the cultivar that produced the most fruits was $\mathrm{cv}$. BRS-Tupy and the lowest producer was cv. Xavante (Table I). This shows that the larger mean leaf area observed in cv. Xavante did not result in proportional photoassimilation to produce fruits of larger size and weight.

Curi et al. (2015), in two growing cycles in Lavras-MG (11/2010 and 12/2011), reported greater number of fruits with cv. Guarani compared with numbers from BRS-Tupy, Cherokee and Xavante cultivars.

According to Tullio and Ayub (2013), this large variation can be explained by the agroclimatic differences of each region and year, even using the same cultivar. This may have influenced the somewhat different performance of the same cultivars in different locations. Temperature, soil, nutrient availability, precipitation and climate, among other factors may also influence this difference.

Curi et al. (2015) evaluated blackberry cultivars at high density $\left(6,667\right.$ plants $\left.\mathrm{ha}^{-1}\right)$ in the city of Lavras-MG and obtained the same results. Nevertheless, the higher productivity shown by 
TABLE I

Mean leaf area (MLA), green leaf mass (GLM) mass of leaf dry matter (MLDM), average fruit size (AFS), average fruit mass (AFM), number of fruits per plant (NFP) and productivity according to the cultivar of blackberry. Chapecó, SC, 2018.

\begin{tabular}{|c|c|c|c|c|c|c|c|}
\hline Cultivar & $\begin{array}{l}\text { MLA } \\
\left(\mathrm{cm}^{2}\right)\end{array}$ & GLM (g) & MLDM (\%) & $\operatorname{AFS}\left(\mathbf{c m}^{3}\right)$ & $\begin{array}{c}\text { AFM } \\
\text { (g) }\end{array}$ & $\begin{array}{c}\text { NFP } \\
\left(\text { planta }^{-1}\right)\end{array}$ & Prod. $\left(\mathrm{Kg} \mathrm{ha}^{-1}\right)$ \\
\hline Cherokee & $36.95 \mathrm{~b}^{*}$ & $3.91 \mathrm{~b}$ & $45.03^{\mathrm{ns}}$ & $2.65 \mathrm{~b}$ & $2.77 \mathrm{~b}$ & $200.80 \mathrm{~b}$ & $1,251.41 \mathrm{~b}$ \\
\hline Guarani & $53.26 \mathrm{~b}$ & $5.87 \mathrm{~b}$ & 44.71 & $2.67 \mathrm{~b}$ & $3.00 \mathrm{~b}$ & $138.25 \mathrm{~b}$ & $923.61 \mathrm{bc}$ \\
\hline BRS-Tupy & $45.70 \mathrm{~b}$ & $5.57 \mathrm{~b}$ & 48.38 & $5.05 \mathrm{a}$ & $5.15 \mathrm{a}$ & $277.40 \mathrm{a}$ & $3,177.57 \mathrm{a}$ \\
\hline Xavante & $95.50 \mathrm{a}$ & $12.53 \mathrm{a}$ & 43.48 & $2.67 \mathrm{~b}$ & $2.53 \mathrm{~b}$ & $55.50 \mathrm{c}$ & $314.77 \mathrm{c}$ \\
\hline CV (\%) & 16.51 & 20.34 & 6.44 & 15.59 & 7.17 & 15.31 & 17.9 \\
\hline
\end{tabular}

*Values followed by the same letter in the column do not differ significantly (Tukey's test, $\mathrm{P} \leq 0.05$ ).

${ }^{\mathrm{ns}}$ not significant.

the cultivars in Lavras-MG related to the higher planting density.

Regarding the chemical analyses of the various cultivars (Table II), we observed that only the soluble solids variable showed no significant difference. Cultivar Xavante had the highest concentration of total anthocyanins and cv. BRSTupy presented a reduction of $20.6 \%$, followed by Cherokee and Guarani, with a concentration reduction of $33.6 \%$.

For Hassimotto et al. (2008) in studies carried out in Caldas - MG, cv. Guarani gave higher results (194.0 mg per $100 \mathrm{~g} \mathrm{FM}$ ) and cv. BRS-Tupy gave lower results (116.0 mg per $100 \mathrm{~g}$ FM). These differences may be explained by intrinsic factors in the cultivars, including pedoclimatic factors.

For flavonoids, we observed that cv. Xavante gave higher mean values (Table II). Fu et al. (2015) studied the raspberry tree (Rubus hirsutus Thunb.), native to China, and observed higher concentrations of flavonoids in the smaller fruits. Similar results were observed in this study, comparing the variables of mean volume of fruit and flavonoids, with cv. Xavante being among those with smaller average volume of fruit while producing greater concentration of flavonoids than did the other cultivars.

We observed that cv. Xavante showed higher concentrations of phenolic compounds than did cv. BRS-Tupy (a 35.6\% reduction, Table II). According to Vizzotto et al. (2012), cultivars that do not have spines give higher concentrations of phenolic compounds in fruits. These differences may be related to the synthesis of secondary compounds by plants, which, when they do not present spines in the primocanes, can produce greater concentrations of other compounds.

Souza et al. (2014) compared blackberry with other small fruit species and found that the former stood out in terms of highest antioxidant activity and highest levels of phenols, flavonoids, anthocyanins and carotenoids, compared to red raspberry, strawberry, sweet cherry and blueberry. This was true even considering differences among the various cultivars.

\section{EXPERIMENT 2}

For average mean leaf area, we observed that the blackberry trees subjected to drastic winter pruning gave larger leaves than did the three primocanes plants (Table III). The plants with two and four primocanes gave leaves of intermediate size, not differing significantly from one another or from plants subjected to the other treatments in this study. The greater leaf size in the trees subjected to drastic winter pruning, may be related to the intensity of pruning and the vigor of the plant.

Evaluating the average green matter mass of the leaves of the plant with various types of pruning, we showed that those subjected to drastic 
TABLE II

Chemical analysis of solubles solids, total anthocyanins, flavonoids and phenolic compounds for the different cultivars of Blackberry. Chapecó, SC, 2018.

\begin{tabular}{ccccc}
\hline Cultivar & $\begin{array}{c}\text { Solubles Solids } \\
\left({ }^{\circ} \text { Brix) }\right.\end{array}$ & $\begin{array}{c}\text { Total Anthocyanins }(\mathbf{m g} \\
\left.\mathbf{1 0 0 ~}^{-1}\right)\end{array}$ & $\begin{array}{c}\text { Flavonoids }(\mathbf{m g} \\
\left.\mathbf{1 0 0 ~}^{-1}\right)\end{array}$ & $\begin{array}{c}\text { Phenolic compounds (mg } \\
\left.\text { GAE 100 } \mathbf{g}^{-1}\right)\end{array}$ \\
\hline Cherokee & $8.21^{\mathrm{ns}}$ & $133.44 \mathrm{c}^{*}$ & $54.24 \mathrm{~b}$ & $133.00 \mathrm{ab}$ \\
Guarani & 8.22 & $121.54 \mathrm{c}$ & $50.67 \mathrm{~b}$ & $150.98 \mathrm{ab}$ \\
BRS-Tupy & 8.76 & $152.41 \mathrm{~b}$ & $49.08 \mathrm{~b}$ & $127.51 \mathrm{~b}$ \\
Xavante & 7.90 & $191.97 \mathrm{a}$ & $68.44 \mathrm{a}$ & $198.08 \mathrm{a}$ \\
CV (\%) & 8.25 & 4.59 & 5.24 & 17.51 \\
\hline
\end{tabular}

*Values followed by the same letter in the column do not differ significantly (Tukey's test, $\mathrm{P} \leq 0.05$ ).

${ }^{\mathrm{ns}}$ not significant.

winter pruning produced greater mass of green leafy matter than did plants with three primocanes (Table III).

There were no significant differences among the various types of pruning with respect to dry mass content of leaves (Table III). This suggests that blackberry trees subjected to various pruning types do not present variations in water content in leaf tissues.

We observed that plants with two and three primocanes gave larger fruits on average, differing significantly from those with drastic pruning (26.14\% smaller, Table III).

The plants with four primary primocanes gave the greatest number of fruits per plant (Table III). The lowest number of fruits produced per plant and the lowest average fruit mass were found in plants subjected to drastic winter pruning. However, the plants with two, three and four primary primocanes did not differ significantly from one another, with average weight $5.28 \mathrm{~g}_{\text {fruit }}{ }^{-1}$.

We observed that, with the increase of the number of primocanes per plant up to the fourth branch, there was an increase in the number, size and average mass of the fruits (Table III). According to Tullio and Ayub (2013) the productivity of the blackberry was directly related to the number of primocanes that the plant possesses.
Tullio and Ayub (2013) observed that the increase in the number of fruits per plant occurred up to 7.8 primocanes per plant. As for average mass, Campagnolo and Pio (2012a) obtained fruits with greater mass using drastic winter pruning, because of the low number of fruits produced in the plant, different from the result we reported in the present work.

Takeda (2002) reported inferior quality of plants with 12 primocanes compared to plants with lower numbers of primocanes. When reaching a high number of primocanes, there was a decrease in the quality of the fruits harvested, in addition to a hindering of the internal and external handling of the cultivated plants, as well as of the harvest.

Broetto et al. (2009) evaluated cv. Xavante and noticed that the number of fruits was influenced by the intensity of the pruning, because the greater number of buds left after the pruning allowed an increase in the quantity of fruits.

Plants with drastic winter pruning showed lower averages in productive characteristics (Table III). This may have an influence on the supply of reserves, since these plants will have to form their aerial parts even before beginning production in the same cycle. This is different from other treatments in which they had pre-defined primocanes in the previous cycle. Thus, the plant needs to form its 
TABLE III

Mean leaf area (MLA), green leaf mass (GLM) mass of leaf dry matter (MLDM), average fruit size (AFS), average fruit mass (AFM), number of fruits per plant (NFP) and productivity for the various numbers of primocanes in blackberry cultivar BRS-Tupy, in Chapecó, SC, 2018.

\begin{tabular}{|c|c|c|c|c|c|c|c|}
\hline $\begin{array}{l}\text { Numbers of } \\
\text { primocanes }\end{array}$ & $\begin{array}{l}\text { MLA } \\
\left(\mathrm{cm}^{2}\right)\end{array}$ & GLM (g) & MLDM (\%) & $\operatorname{AFS}\left(\mathrm{cm}^{3}\right)$ & $\begin{array}{c}\text { AFM } \\
\text { (g) }\end{array}$ & $\begin{array}{c}\text { NFP } \\
\left(\text { planta }^{-1}\right)\end{array}$ & Prod. $\left(\mathrm{Kg} \mathrm{ha}^{-1}\right)$ \\
\hline Drastic (0) & $65.35 \mathrm{a}^{*}$ & $7.82 \mathrm{a}$ & $48.29^{\mathrm{ns}}$ & $3.87 \mathrm{~b}$ & $3.70 \mathrm{~b}$ & $68.6 \mathrm{~d}$ & $570.18 \mathrm{~d}$ \\
\hline 2 & $51.92 \mathrm{ab}$ & $6.29 \mathrm{ab}$ & 46.27 & $5.44 \mathrm{a}$ & $5.65 \mathrm{a}$ & $205.4 \mathrm{c}$ & $2,571.03 \mathrm{c}$ \\
\hline 3 & $45.70 \mathrm{~b}$ & $5.57 \mathrm{~b}$ & 48.38 & $5.05 \mathrm{a}$ & $5.15 \mathrm{a}$ & $277.4 \mathrm{~b}$ & $3,177.57 \mathrm{~b}$ \\
\hline 4 & $55.42 \mathrm{ab}$ & $6.17 \mathrm{ab}$ & 47.19 & $4.94 \mathrm{ab}$ & $5.08 \mathrm{a}$ & $391.4 \mathrm{a}$ & $4,417.84 \mathrm{a}$ \\
\hline CV (\%) & 18.03 & 17.57 & 5.28 & 12.91 & 9.52 & 7.20 & 9.92 \\
\hline
\end{tabular}

*Values followed by the same letter in the column do not differ significantly (Tukey's test, $\mathrm{P} \leq 0.05$ ).

${ }^{\text {ns }}$ not significant.

TABLE IV

Chemical analysis of solubles solids, total anthocyanins, flavonoids and phenolic compounds for the various numbers of primocanes in blackberry cultivar BRS-Tupy, in Chapecó, SC, 2018.

\begin{tabular}{|c|c|c|c|c|}
\hline $\begin{array}{l}\text { Numbers of } \\
\text { primocanes }\end{array}$ & $\begin{array}{c}\text { Solubles Solids } \\
\text { ( }{ }^{\circ} \text { Brix) }\end{array}$ & $\begin{array}{c}\text { Total Anthocyanins } \\
\left(\mathrm{mg} 100 \mathrm{~g}^{-1}\right)\end{array}$ & $\begin{array}{l}\text { Flavonoids } \\
\left({\left.\mathrm{mg} 100 \mathrm{~g}^{-1}\right)}\right.\end{array}$ & $\begin{array}{l}\text { Phenolic compounds } \\
\left(\mathrm{mg} \mathrm{GAE} 100 \mathrm{~g}^{-1}\right)\end{array}$ \\
\hline Drastic & $7.47 b^{*}$ & $137.23^{\mathrm{ns}}$ & $43.73 b$ & $112.88^{\mathrm{ns}}$ \\
\hline 2 & $8.22 \mathrm{ab}$ & 136.67 & $51.18 \mathrm{a}$ & 122.46 \\
\hline 3 & $8.76 \mathrm{a}$ & 152.41 & $49.08 \mathrm{ab}$ & 127.51 \\
\hline 4 & $8.48 \mathrm{a}$ & 149.58 & $43.99 \mathrm{ab}$ & 118.51 \\
\hline CV (\%) & 5.86 & 10.77 & 8.29 & 13.20 \\
\hline
\end{tabular}

*Values followed by the same letter in the column do not differ significantly (Tukey's test, $\mathrm{P} \leq 0.05$ ).

${ }^{\text {ns }}$ not significant.

primocane in a productive cycle so that it will bear fruit in the next cycle.

Regarding chemical variables, we observed significant differences for soluble solids and flavonoids (Table IV). Soluble solids in plants with three and four primary primocanes were significantly different from those subjected to drastic pruning.

We observed that plants with two primary primocanes had higher concentrations of flavonoids in the fruits, but differed only from plants with drastic winter pruning (Table IV).

According to Jacques and Zambiazi (2011), the distribution of flavonoids in a plant is directly related to access to light, primarily ultraviolet rays that influence the formation of this pigment. Thus, plants with two primocanes admitted more ultraviolet rays and gave higher concentrations of flavonoids in fruits, different from those without primocanes (drastic pruning) that presented greater vegetative development.

$\mathrm{Fu}$ et al. (2015) reported that the smaller the fruit size, the higher the concentration of flavonoids. This explains the progressively higher flavonoid concentrations in plants with 2, 3 and 4 primocanes and in winter drastic pruning plants, where there were smaller fruit sizes.

There were no significant differences for anthocyanins and phenolic compounds for the various numbers of primary primocanes (Table IV).

Finally, under the conditions of this experiment, bioactive compounds varied with the cultivars and some of them were influenced by pruning in the cultivar BRS-Tupy. The question remains as to whether various prunings in the other cultivars will affect the content of these compounds. 
The cultivar BRS-Tupy was more productive with fruits of better physical quality. The cultivar Xavante stood out in terms of bioactive compounds of the fruits. Drastic winter pruning in the cultivar BRS-Tupy is not recommended. Maintaining four primocanes resulted in fruits with better productivity. Two primocanes tend to produce fruits with better bioactive compounds.

\section{ACKNOWLEDGMENTS}

This work was supported by the Fundação de Amparo à Pesquisa e Inovação do Estado de Santa Catarina (FAPESC) Brazil (07/2015); and The Frutplan Mudas Ltda.

\section{REFERENCES}

BROETTO D, BOTELHO RV, PAVANELLO AP AND SANTOS RP. 2009. Organic cultive of blackberry cv. Xavante in Guarapuava - PR. Revista Brasileira de Agroecologia 4: 2208-2212.

CAMPAGNOLO MA AND PIO R. 2012a. Drastic pruning for the production of blackberry in subtropical regions. Pesqui Agropecu Bras 47: 934-938.

CAMPAGNOLO MA AND PIO R. 2012b. Productive of 'Tupy' blackberry under different pruning time. Cienc Rural 42: 225-231.

CURI PN, PIO R, MOURA PHA, TADEU MH, NOGUEIRA PV AND PASQUAL M. 2015. Production of blackberry and redberry in Lavras - MG, Brazil. Cienc Rural 45: 1368-1374.

FERREIRA DS, ROSSO VV AND MERCADANTE AZ. 2010. Bioactive compounds of blackberry fruits (Rubus spp.) grown in Brazil. Rev Bras Frutic 32: 664-674.

FERREIRA LV, PICOLOTTO L, COCCO C, FINKENAUER D AND ANTUNES LEC. 2016. Blackberry yield on different trellis systems. Cienc Rural 46: 421-427.

FU Y, ZHOU X, CHEN S, SUN Y, SHEN Y AND YE X. 2015. Chemical composition and antioxidant activity of Chinese wild raspberry (Rubus hirsutus Thunb.). LWT - Rev Food Sci T 60: 1262-1268.

GEORGÉ S, BRAT P, ALTER P AND AMIOT MJ. 2005. Rapid determination of polyphenols and vitamin $\mathrm{C}$ in plant-derived products. J Agri Food Chem 53: 1370-1373.

HASSIMOTTO NMA, MOTA RV, CORDENUNSI BR AND LAJOLO FM. 2008. Physico-chemical characterization and bioactive compounds of blackberry fruits (Rubus sp.) grown in Brazil. Rev Food Sci T 28: 702-708.

HIRSCH GE, FACCO EMP, RODRIGUES DB, VIZZOTTO M AND EMANUELLI T. 2012. Physicochemical characterization of blackberry from the Southern Region of Brazil. Cienc Rural 42: 942-947.

JACQUES AC AND ZAMBIAZI RC. 2011. Phytochemicals in blackberry. Semin-Cienc Agrar 32: 245-260.

LEES DH AND FRANCIS FJ. 1972. Standardization of pigment analyses in cranberries. HortScience 7: 83-84.

SOUZA VR, PEREIRA PAP, SILVA TLT, LIMA LCO, PIO R AND QUEIROZ F. 2014. Determination of the bioactive compounds, antioxidant activity and chemical composition of Brazilian blackberry, red raspberry, strawberry, blueberry and sweet cherry fruits. Food Chem 156: 362-368.

TADEU MH, SOUZA FBM, PIO R, VALLE MHR, LOCATELLI G, GUIMARÃES GF AND SILVA BEC. 2015. Drastic summer pruning and production of blackberry cultivars in subtropical áreas. Pesqui Agropecu Bras 50: 132-140.

TAKEDA F. 2002. Winter pruning affects yield components of 'Black Satin' eastern thornless blackberry. HortScience 37: 101-103.

TULLIO L AND AYUB RA. 2013. Production of blackberry cv Tupy, depending on the intensity of pruning. SeminCienc Agrar 43: 1147-1152.

VILLA F, DA SILVA DF, BARP FK AND STUMM DR. 2014. Blackberries produced in subtropical region in function of pruning, conduction systems and number of stems. Revista Agrarian 7: 521-529.

VIZZOTTO M, RASEIRA MCB, PEREIRA MC AND FETTER MR. 2012. Phenolic content and antioxidant activity of different genotypes of blackberry (Rubus sp.). Rev Bras Frutic 43: 853-858. 